\title{
Justice, Culture and Subjectivity
}

Patrice Schuch - Federal University of Rio Grande do Sul (UFRGS)

\begin{abstract}
This paper examines the relationships between new legal technologies and the formation of new social sensibilities. Based on ethnographic work on the implementation of restorative justice in Brazil, it seeks to understand the connection between the mechanisms for diffusing new legal models and different forms of government. The article is primarily focused on understanding a particular constellation of new legal frameworks and subjectivities in a context where the rhetoric of rights is associated with a promotion of development and 'modernity.' The paper argues that focusing attention on subjectivities is essential to understanding how these transformations are currently unfolding.
\end{abstract}

Keywords: justice, subjectivity, forms of government

\section{Resumo}

Este trabalho visa entender a relação entre novas tecnologias jurídicas e a formação de novas sensibilidades sociais. Partindo de uma etnografia sobre a implantação da justiça restaurativa no Brasil, procura-se compreender a interconexão entre os mecanismos de difusão de novos modelos jurídicos e formas de governo. $\mathrm{O}$ artigo focalizará prioritariamente a compreensão desta constelação particular entre novos modelos judiciais e subjetividades, em um contexto em que a retórica dos direitos se associa à promoção do desenvolvimento e "modernidade". Argumenta-se que a atenção para as subjetividades é fundamental para a compreensão dos modos como se efetivam as transformações em curso.

Palavras-chave: justiça, subjetividade e formas de governo 


\section{Justice, Culture and Subjectivity}

\section{Patrice Schuch - Federal University of Rio Grande do Sul (UFRGS)}

In April 2009 I interviewed Cinara, a teacher working as a manager in the implementation of 'restorative justice' in the schools of Porto Alegre, in the south of Brazil. As I shall show later in this paper, restorative justice is a form of judicial intermediation that has been implemented and developed in Brazil from 2005 to the present. Its aim is to manage conflict by enabling communication and the expression of emotion between the accused, his or her victim and the intensive participation of the community. Cinara's words express her engagement with this new juridical technology for conflict management':

I always joke that in fact my life literally changed. Not only a change of attitude, of personality.... Previously, there had been a teacher who knew me during that very explosive phase, she carried out an audit in my school. And now when she sees me she doesn't even recognize me (...) It's true. Spending one year coordinating [restorative meetings] also led me to change, because then I had to really embrace. (...) When I started, Viviam was my supervisor. From the beginning she told me that I was good at getting people together, even though I had this hot temper. So I think I already knew how to help them, I cared about them, and because of that I didn't even have a life of my own... The same applies to being a teacher. I've always wanted to be a teacher. My mother never let me, but that's what I had always wanted. I think that, if you want to work with human beings, as a profession it allows you to get closer to them. So I think it offers this opportunity, it did [for me]. My first training was in the arts. I worked for ten years with a theater group. I also saw this as an occupation that kept me closer to human beings. So I have always cared about people, in terms of what they are. I already had that in me.

1 In this paper, I shall use pseudonyms to refer to the research subjects with whom I interacted privately. When I refer to statements published in other media and/or to institutional consultants or managers whose professional information are in the public domain (for instance, a UNICEF or UNESCO consultant) the person's real name is kept. 
Cinara is white, about 35 years old, and has worked since 2007 in restorative justice. Originally trained in the arts, she worked as an elementary school teacher for over 10 years. At the time of the above conversation, she was working full-time supervising restorative practices in Porto Alegre's municipal schools. She had been temporarily seconded to the Child and Youth Court (Juizado da Infância e Juventude: JIJ) as part of an agreement between the latter and the Municipal Education Office. Her co-workers were not teachers but court clerks and professionals hired by the Judiciary to disseminate the values and ideas of restorative justice. Cinara shared a small room with three female colleagues, located in the facilities of a Catholic church close to downtown Porto Alegre. The headquarters of the restorative justice project were moved there in March 2009 after three years based in the JIJ building, within the special court for enforcement of socio-educational measures. ${ }^{2}$

I met Cinara in 2007 during my ethnographic fieldwork on introductory classes in restorative practices. In the above conversation with her, I learned that the meanings she attributed to her participation in the legal reform of child and adolescent care in Brazil since implementation of the 1990 Child and Adolescent Statute largely revolved around her sense of a calling for the work of caring for others and listening to them. She believes that a close affinity exists between these qualities and the Christian education she received as a child; her grandfather had been a pioneer in the opening of a Spiritualist Center in Porto Alegre. Cinara emphasized spirituality, especially charity and forgiveness, as a bridge between her own life trajectory and restorative practices. But as the quote also makes clear, while Cinara argued that she had something of herself to give to this new legal intervention project (restorative justice), she also claimed to have received something significant in return: a transformation in her own subjectivity: her experience allowed her to learn how to exert greater control over her own emotions.

I decided to begin this text with Cinara's story because it contains a series of elements that can help us understand how processes of legal reform in the area of children and adolescents are unfolding in contemporary Brazil. These elements include: particular constellations of moral and religious meanings; legal configurations stemming from national and international processes

2 Socio-educational measures target adolescents accused of committing offenses. According to the 1990 Child and Adolescent Statute, these are: internment in an educational facility; semi-freedom; assisted freedom; community service; and warnings. 
for expanding rights; the rhetorical association of human rights with the notion of national development; and the introduction of new technologies for managing subjectivities. I believe that these changes, which largely center on a rights-based discourse, are not just about legal principles and regulations. They encompass the management of social sensibilities and subjectivities, and are part of broader changes in the art of government in a post-democratization context.

I suggest that contemporary modes of managing children and adolescents in Brazil can be understood through an analysis of two interrelated processes: on one hand, the emphasis on a rhetoric of rights as instruments for 'modernization,' social development, and the consolidation of democracy; on the other, the attempt to create 'modern sensibilities' and new kinds of personhood based on the values of individuality, autonomy and self-responsibility. These two clusters of relations are fundamental for the formation of a new person, the 'subject of rights,' as well as for the reconfiguration of a new sense of nationhood. I am interested in understanding the processes leading to the creation of this new social person, as well as how new technologies of constructing the self intersect with multiple moralities (especially religious) and other technologies of social intervention - for instance, welfare practices based on 'assistance.' This approach questions the more unilinear discourses on 'modernity,' development and re-democratization.

These arguments are based on ethnographic research carried out since 2006 on the practices and meanings associated with the implementation of restorative justice in the Brazilian state of Rio Grande do Sul. My focus is on restorative practices in the Child and Youth Court (Vara da Infância e Juventude) in the state capital of Porto Alegre. I also draw on data collected previously concerning this same area of intervention, which I have been following for the past eight years since concluding my $\mathrm{PhD}$ research in social anthropology. In my previous work, I examined the practices and meanings associated with the management of children and adolescents by professionals working in the legal field relating to young offenders (Schuch, 2009). In the case of both these research topics - juvenile offender justice and the implantation of restorative justice - I have carried out ethnographic observation of professional training courses on management of child and adolescent management, as well as interviews, informal conversations with these agents and their target public, and documental research on ongoing processes and 
their institutional contexts. I have also participated in hearings and other judicial proceedings, made ethnographic observations at the Registry Court and the 'Parent School' (during my doctoral research), and carried out analyses of restorative circles recorded on DVD (during my research on restorative practices). The present analysis draws mostly on the interviews with agents working in the legal field of implementing restorative practices. Its broader background includes data collected during my studies of modes of governance of children and adolescents in Brazil.

I have analyzed the cluster of ideas surrounding this legal experience, as well as the tensions that arise during its implementation, on an earlier occasion (Schuch 2008b). Here I shall emphasize the meanings involved in the incorporation of restorative justice according to some of its champions. I seek to understand the relationship between legal technologies and the formation of new social sensibilities in a context where the rhetoric of citizen rights is closely associated with the promotion of development and 'modernity.'

\section{The Political Economy of Juridical Models and the Threefold Status of Subjectivity}

This way of framing these problems has received some attention by anthropologists interested in studying contemporary forms of government and their relations to various technologies involved in the formation of subjects and subjectivities (Abu-Lughod 2003; Biehl 2004, 2005; Biehl and Eskerod 2005, 2007; Biehl, Good and Kleinman 2007; Fassin 2007; Ong and Collier 2005). In Brazil, however, studies of this kind are few and far between. Brazilian analyses of the country's judicial system and of changes in the diverse field of conflict management have privileged an institutional perspective that seeks to understand both the dynamics of meanings and the operation of different bodies within the legal and law enforcement system. This approach has yielded robust and innovative studies on the workings of power and its relations to particular social sensibilities from a number of different analytical standpoints: specificities related to Brazil's culture and legal traditions (Cardoso de Oliveira 2002, 2010; Kant de Lima 1989, 1995, 1999, 2003); the effects of new legal categories on bureaucratic routines and the visibility of certain social groups and action-related problematics (Beraldo de Oliveira 2010; Debert and Beraldo de Oliveira 2007; Fonseca 2004; Fonseca 2010; Fonseca and 
Cardarello1999; Neves 2010; Schuch 2009; Ribeiro 1996, 2009); and/or the negotiations of meaning and action in multiple institutions, according to the different social and symbolic worlds of the agents concerned (Bonetti 2001; Ferreira and Schuch 2010; Muniz 1996; Mello 2011; Schritzmeyer 2007).

In his review of these studies, Rifiotis (2007) appeals for an anthropology that would privilege the "subject of rights" over the "rights of subjects." The problem with this proposal, however, is that 'subjects' are in a sense determined by the legal universe of 'rights.' In any case, it seems reasonable to suggest that the existence of this rich corpus of studies on Brazil's legal institutions, along with the revitalization of the country as a whole after twenty years of return to democratic rule, may point to new research opportunities. Perhaps this is the right moment to 'explode' the analysis of institutional fields in order to delve into the complexities of the subjects 'of rights' - but also of something else: an understanding of the diverse circuits in which legal practices and moral sensibilities gain social life. In this way we can reach a better understanding of the complexities of the processes that associate the diffusion of rights in Brazil with the country's social development and 'modernization.' In this study I attempt precisely this approach by emphasizing the problematization of subjectivity and its threefold character: as an analytical category, as an instrument for bringing about new forms of government, and as the very grounding for agency.

Here I follow Nader's (1994) proposal for exploring what she called the "political economy of legal models" - that is, the role of legal hegemonies in the configuration and reconfiguration of culture. I take this as inspiration to inquire into the relations between international scenarios and the political and cultural ideologies informing the development of new governmental practices. This becomes especially important in the Brazilian case, for two reasons. The first one is the recent democratization process. As in other countries emerging from authoritarian rule, the reformulation of the justice system and the implementation of policies for promoting and protecting basic human rights have been essential elements in the production of discourses on development and modernization that are frequently associated with the search for political legitimacy in the international arena (Wilson 1990, 1997). On the other hand, in Brazil the value attributed to community engagement in the creation of legal practices clearly promotes the formation of a new social actor - the 'subject of rights' - with its own responsibilities and freedoms. 
Following Michel Foucault (1979) and Nikolas Rose (1999, 2006), I propose that freedom should not be taken as an opposite of government, but as one of its most effective instruments. This approach opens up a whole new field of inquiry into the elements, techniques, norms, methods and technologies through which the question of how to live is posed, but also reconfigured, in a multiplicity of practices. When introduced in new contexts, these legal technologies and development projects are appropriated in unique ways, giving rise to negotiations, conflicts and space for re-interpretations and other possible uses (Asher 2004; Gupta 2001; Sahlins 1997). A diverse scenario is formed, therefore, in which the practical implementation of intervention projects can reshape the very means of their dissemination - hence the interest in understanding relations between legal practices, culture and subjectivity. I believe that attention to subjectivities - understood as a set of modes of perception, affect, thought, desire, fear, and so forth, that animates acting subjects; and as a set of cultural forms that shape, organize and provoke these models of thought and affect (Ortner 2006) - is fundamental for understanding contemporary changes. It provides access to the moral sensibilities that operate in the interstices of the legal domain.

My research interest in subjectivity as an analytical category overlaps with a curiosity about how subjectivity also comprises an important category for grasping what is at stake for those who implement restorative justice as a privileged locus for action and pedagogy. In this approach, conflict is understood as an outcome of unattended human needs and an inability to express individual wants socially. Therefore, the transformation of individual subjectivities in the process of understanding, reflecting on and expressing oneself assumes a vital role in the pacification of social relations. From this perspective, my research data unveils a double dynamic. On one hand, as Biehl, Good and Kleinman (2007) have argued, subjectivity appears both as an analytical category and as an instrument by which new modes of government come to life. At the same time, though, subjectivity may also be regarded as a ground for agency (Ortner, 1995, 1999, 2006). In this case, subjectivity becomes essential for understanding the intersection between the promotion of new life management technologies and their deployment, reinterpretation and reformulation in the everyday lives of those who are simultaneously subject to them and co-produce them. 


\section{Reform processes: legal 'modernity' and the struggle against the traditional service 'culture'}

Since 2001 I have been researching legal changes in the field of children and adolescents in Brazil, especially since the introduction of the 1990 Child and Adolescent Statute (Estatuto da Criança e do Adolescente: ECA). As in the case of the current Brazilian Constitution (the so-called 'Citizen Constitution' promulgated in 1988), the Statute followed international guidelines on children's rights. The ECA came into being amidst an expansion in human rights rhetoric following the restoration of democratic institutions and citizen rights to Brazilians after almost twenty years of military dictatorship. More explicitly, it turns children and adolescents into 'subjects of rights' by breaking away from the 'minority' policies characteristic of previous legal frameworks. These new frameworks are based on a notion of 'universal infancy' (Vianna 2002), defined over and above any criteria of social belonging or attributed identity. ${ }^{3}$

The definition of children and adolescents as 'subjects of rights' stems from and expresses a concern with the governance of children and adolescents in Brazil. On a previous occasion (Schuch 2009), I proposed a threefold classification of intervention frames: i) a hygienic-sanitarist frame, aimed at producing healthy and civilized populations, part of the processes of national integration and unification in the early twentieth century (1900-1950); ii) a modernist frame focused on national development (1950-1980) against the backdrop of projects for strengthening the state apparatus and investing in the 'modernization' of the state and the family, which alternated ambiguously between repression and surveillance; iii) the contemporary frame of rights (1980-present), which invests in community participation in sectorial policies and reconfigures children and adolescents as 'subjects of rights' to be integrally protected by the state, family and community. This frame echoes broader discussions in the international arena in which representations of the Brazilian nation state are refracted by the new rhetorical emphasis on the defense of human rights in general and child and adolescent rights in particular.

Here I follow other recent studies on the management of children and adolescents in Brazil (e.g. Fonseca 1995, 2000, 2004; Fonseca and Schuch 2009; Gregori 2000; Gregori and Silva 2000; Pilotti and Rizzinni 1995; Ribeiro 1996,

3 On the category of 'minority' and its legal and social meanings, see Vianna (1999, 2002). 
2009; Vianna 1999, 2002) by exploring the complexities of the legal reform process engendered by the introduction of the human rights idiom into this field of social intervention. ${ }^{4}$ My ethnographic research has indicated that one of the most powerful instruments for transforming the practices and meanings of social intervention in the management of children and adolescents has been precisely a rhetoric that contrasts 'legal modernity' to the 'traditional culture' of services in the field of children and adolescents.

Rather than taking this opposition for granted, it can be analyzed as part of an effort to reconfigure authorities and modes of government within this field of intervention. My ethnographic research has shown that those heading the processes of institutional change tended to associate national development, 'modernity' and legal innovation in a form that has been crucial to the production of what I call a "new field of services for children and adolescents" in Brazil. This formula is inspired by Bourdieu's (1989) notion of the field, which emphasizes conflict and continuous negotiation over power and symbolic capital. It is used here not only to describe the local negotiations over the implementation of new ways of managing children and adolescents, but also to capture the circulation of hegemonic international principles. As some anthropologists of law have remarked, the reception of international legal models is highly heterogeneous, and is largely determined by the particular interests of local legal cultures (Gardner, 1980; Wilson, 2000). When analyzing the adoption of international principles, we always have to take into account a process Dezalay and Garth (1996) called 'internalization,' that is, the ways in which national actors and institutions incorporate hegemonic discourses with a view to changing local realities.

The implementation of the ECA played a fundamental role in changing the way of governing children and adolescents in Brazil. After its enactment, the new law was popularized through the dissemination of bibliographic materials on the subject, as well the systematic organization of seminars and capacity-building courses for managers and professionals working with children and adolescents. This process heavily involved the presence of international experts from various development organizations: UNICEF consultants and international lawyers and activists who, along with local actors, sought

4 For a comparative approach to Argentina concerning the place of 'justice for minors' and the extent of its reach in the legal field, see Villalta (2004). 
to change what they identified as 'traditional' models for attending to children and adolescents in the country. In the aftermath of Brazil's redemocratization, the ECA represented a break with authoritarian and discretionary practices in the management of children and adolescents. In line with international human rights norms, the ECA was heralded as a democratic and 'modern' piece of legislation. Most professionals and activists working with young people celebrated the new law not only as a symbol of democracy itself, but also as a vehicle for the 'modernization' of Brazilian society.

With the ready availability of financial aid and symbolic capital from international institutions, especially UNICEF, the 1990 s were a busy time for meetings, seminars and courses on how to protect the rights of children and adolescents (Macedo 2009; Schuch 2009, 2010). In these meetings, the leading actors were the international consultants and judges who had the knowledge to teach the new legal principles, and who deployed the human rights rhetoric as a source of legitimacy. To use Bourdieu's concept, they possessed significant symbolic capital in a society moving towards the valorization of a rights-based discourse: they had legal knowledge relevant to the struggles for authority between various actors and institutions involved in the management of children and adolescents.

The dissemination of this kind of knowledge was an important facet of the implementation of the ECA. In the Brazilian state of Rio Grande do Sul, this process involved the creation of a 'Library of Children's Rights' at a private university in the city of Caxias do Sul in 1994. In the first decade after the enactment of the ECA, consultants from international agencies like UNICEF - in particular Mario Volpi, Antônio Carlos Gomes da Costa and Emílio G. Mendez - released a series of publications. These acquired a life of their own as these professionals also took part in many meetings and seminars aimed towards the 'professional training' of activists and workers in the field of children and adolescents. In these meetings, there was a rhetorical valorization of the ECA as a 'progressive law,' perceived by the participants to contrast with a 'Brazilian culture' of civilizing children and adolescents through a rights-based discourse.

One of the brochures delivered to participants of the Third State Conference on Children and Adolescent Rights in 2002 contains a quote from Deodato Rivera, a social scientist who participated in the elaboration of the new legislation: "The Child and Adolescent Statute is for the twenty first 
century as the Lei Áurea [the 1888 law that abolished slavery in Brazil] was for the past century. It is a civilizing law" (Rivera 1990: 34 ). This quote explicitly identifies the new regulation as a civilizing instrument. The same material includes a passage by the Judge Antônio Fernando do Amaral e Silva, who noted a significant relationship between the reestablishment of democracy and the role played by the new law:

The 1990 Law number 8,069 (ECA) created more than a new legal framework for children and adolescents. It established the democratic rule of law in a sphere where it had been absent throughout our historical formation. It abolished discretion and subjectivism, consecrating the law and dignifying Justice (Amaral e Silva 1990:77-78).

A quote from Dom Luciano Mendes de Almeida, then bishop of Mariana (Minas Gerais State), goes even farther in relating the implementation of the ECA with changes in the country at large:

This Statute will be a seed for transforming this country. Its enactment means a commitment that in Brazil there will be no more lives taken within the maternal womb, no more children without affection, abandoned, malnourished, lost to the streets, seriously damaged in terms of their health and education (Almeida 2001:13).

In spite of the strong rhetoric surrounding the ECA as a civilizing instrument legitimated by international norms, my fieldwork revealed a sharp contradiction between the law and the 'Brazilian culture' of assisting children and adolescents. This image of a cultural context to be civilized by legislation that promotes development and 'modernization' resonates strongly with the discourses on development observed in other ethnographic sites (Ferguson 2006; Gupta 2001; Tsing 2005). These often oppose 'tradition' and 'modernity' and present development as a sort of benevolent machine generating prosperity within its field of action. More than just legitimating the new law, this discursive opposition sought to open up a space for legitimate action by new authorities, practices and knowledge relating to children and adolescents in Brazil - complemented, moreover, by a series of institutional changes in this field of intervention.

The notion of a break with pre-ECA practices and ways of attending to children and adolescents was a powerful call to establish new practices and institutions. In tune with this process, approximately half of the newly founded legal jurisdictions covered by Rio Grande do Sul's Child and Youth 
Court during the nineties were occupied by new magistrates. The appointment of these professionals was based on the supposition that they had not yet been 'contaminated' by the 'old culture' of the service for children and adolescents. But if a 'new culture' had yet to be created, as the judge Dr. Roberta put it, it was equally true that nobody knew how to go about creating one. A judge in Porto Alegre's 'Instantaneous Justice' at the time, Dr. Roberta was one of these newly hired professionals and her own career unfolded in parallel with the consolidation of new ways of managing children and adolescents. While assessing the ECA implementation process, she emphasized the difficulties she had encountered during her early career as a magistrate. She related her inexperience as a new professional to the novelty of the ECA's principles.

We went to the jurisdictions and began to work on January 3, 1991, with no previous preparation whatsoever, since our academic training had been based on the Minors' Code. I don't know if you can fathom our despair when a former Minors' Commissioner entered my room at $6 \mathrm{pm}$ with four adolescents that are today called 'juvenile offenders' and said, "I came to deliver them because the minors' judge has to see them." I looked at that situation and thought, "What now? What is the legislation?" I did not have the ECA. Nobody had told us that we should have received a copy, because the general idea was that the judge must know about the legislation. (Dr. Roberta, child and adolescent judge).

Faced with this situation, the Rio Grande do Sul's Judiciary decided to create an institution called the 'Citizenship Department.' According to Dr. Roberta, this department was responsible for ensuring the implementation of the ECA during 1991 and 1992 - to "generate debate on the new law," as she said. This principle of "generating debate on the new law" was carried out by means of public seminars and meetings on the subject. These were the chief mechanism for diffusing the new legal guidelines and, at the same time, a way of training professionals in the legal field to handle the new legislation, and a way of reinforcing legal authority itself.

One event stressed by Dr. Roberta was the "March for the Implementation of the ECA" organized by the Judiciary, which covered three hundred municipalities in the state of Rio Grande do Sul from 1992 onwards. The 'March' consisted of public meetings to distribute copies of the new legislation and discuss the establishment of Tutelary Councils and a Municipal Council for the 
Rights of Children and Adolescents in each city. Dr. Roberta referred to these meetings as 'cultural training.' According to her, the gap between the new legislation and previous social practices was perceived to be so huge that, at the time, she decided to use her private car to deliver the ECA publicity materials in her trips to the different municipalities. Other judges in the same situation did the same thing. Referring to this experience, she stressed:

I do not tell this story so people will say she is devoted to the cause... Because the truth is that we were totally desperate! Everything was falling on our heads, because there was a law stating what was supposed to happen, but nobody was moving a finger to follow it. Society kept asking us to act as the former minors' judges. (Dr. Roberta, child and adolescent judge).

Although Dr. Roberta's testimony emphasized the leadership role of the Judiciary in implementing the ECA, it is also true that major changes in the institutional structure of the Executive were also made during the first decade. The Civil Police increased the number of chief officers in the Special Department for Children and Adolescents (Departamento Especializado da Criança e do Adolescente: DECA) created in the aftermath of the ECA's introduction, and established new, specialized precincts for children and adolescents (present in all ten new JIJ regions throughout the state of Rio Grande do Sul). Fieldwork has shown, however, that the ECA's role in reshaping police officers' procedures and worldviews has been far from homogeneous. Thus while the discourse of clerks and officers working in adolescent detention centers more forcefully conveyed the institution's 'repressive' function, police chiefs would emphasize the letter of the law and crime 'prevention.' In this respect, it is significant that the Civil Police invested in appointing new recruits as chief officers. Detectives and clerks, on the other hand, had been in the ranks for longer. All these elements led to an ambiguous context for change within the police institution, riddled with extremely diverse views on the relevance of the legal changes being implemented.

The same contradictory context was noted in the Socio-Educational Service Foundation (Fundação de Atendimento Sócio-Educativo: FASE), previously the State Foundation for the Welfare of Minors (Fundação Estadual do Bem-Estar do Menor: FEBEM). Early institutional changes involved implementing residential units according to a model of 'houses' for children and adolescents at social risk - the target of 'special protection' measures. Since 1995 
specialized units for implementing 'socio-educational measures' for young offenders have sprung up. New internment and semi-freedom units have been established, new employees hired, and investments made in functional capacity-building courses run by international consultants. By 1998 the institution had built new units for socio-educational measures - the Youth Centers - in the first six of the ten regional districts of the Child and Youth Court.

If we consider the first decade after the ECA's introduction, there has been a significant increase both in the population of juvenile offenders and in the "freedom restraint units" where they are sent..$^{5}$ In 1991 there were only five institutions for 241 juvenile offenders, while in 2000 there were fourteen such institutions to attend a much higher population of 700 adolescents. ${ }^{6}$ More recently, in early 2008, there were sixteen FASE units, the new institution for minor internment, catering for 1,100 adolescents in Rio Grande do Sul. ${ }^{7}$ Although the state has some particularities, the upward trend in the number of freedom-deprived or restrained adolescents is evident in Brazilian society as a whole: data from the 2006 National Survey on the Socio-Educational Service to Adolescents in Conflict with the Law (SPDCA/SEDH/PR, 2006) indicate an upward trend for the entire country. According to this document, over a four-year period (2002-2006) there had been a 33.1\% increase in the total number of adolescents interned in socio-educational institutions in Brazil (under internment measures in educational and semi-freedom facilities), rising from 12,051 in 2002 to 15,426 in 2006.

This growth of internment under socio-educational measures in educational facilities was accompanied by an intensive program of "functional capacity building" for new and old professionals in the 'modern' legal principles and directives. In Rio Grande do Sul, around 240 employees who joined the recently inaugurated FEBEM/RS in March 1998 received intensive training from an international consultant experienced in directing institutions for juvenile

5 This increase results in part from the low privilege assigned to socio-educational measures that can be executed without freedom restraint. In Porto Alegre the municipalization of such measures did not start until 2000. Data from the 2006 National Survey on Socio-Educational Services to Adolescents in Conflict with the Law indicate that incarceration policies for youths tend to prevail in Brazil with $60 \%$ of state capitals yet to implement the measures at municipal level (SPDCA/SEDH/PR 2006).

6 Data collected from the FEBEM/RS Research and Planning Unit, referring to the institution's population on the last day of the years 1991 and 2000.

7 The Law number 11,800 established FASE on May 28, 2002. My source of data on the population and number of FASE units was the institution's website, accessed on Jan 20, 2008. Cf. 〈http:|/www.fase.rs.gov.br〉. 
offenders in Costa Rica. The prognosis was promising, since 'new' employees were being placed in the 'new' institutes, trained by an internationally renowned consultant. Nonetheless, the process of regionalization and specialization was extremely tense and marked by continuous revolts among the interns, increases in the number of inmates, accusations of bad management and the constant substitution of directors, reinforcement of the security technologies, and a pervasive rhetoric opposing the service's 'traditional culture' to the ECA's 'legal modernity' in the everyday routines of the institutions.

What was remarkable about Rio Grande do Sul's experience was the high level of institutional instability that accompanied the reform of freedom restraint units and the methods of dealing with young offenders. This reached the point where in March 1998 three youths were burned alive after setting their mattresses on fire within a cell in the Central Institute for Minors (ICM) in the state capital of Porto Alegre. The social worker in charge of the institution blamed these events on the unit's overcrowding: built for a maximum capacity of 80 adolescents, it had 154 inmates at the time of the uprising. She also linked FEBEM's instability to manifestations of the 'old paradigm' for dealing with juvenile offenders. Her explanations failed to prevent several agents from asking for her dismissal, which took place in July 1998.

The social worker was replaced by an attorney who directed the institution between July and December 1998. Among the actions taken by the new director were the legal regulation of internal procedures and the normatization of the service 'profile' in all FEBEM units. Moreover all inmates over eighteen were moved to the same FEBEM unit - the former Central Institute for Minors (ICM), renamed the Center for the Young Adult (Centro do Jovem Adulto: CJA) - which was placed under the supervision of the Penitentiary Services Office (Superintendência dos Serviços Penitenciários: SUSEPE). SUSEPE agents at the School of Penitentiary Services trained the old ICM supervisors, since 'young adults' were supposed to be treated differently from adolescents. In 1998 the Judiciary initiated a regional debate on a new law to regulate the enactment of socio-educational measures. The FEBEM director who took office in 1999 expressed strong resistance to this idea: she preferred to invest in functional capacity-building aimed at "human recycling," as Oliveira (2000: 14) put it. But the succession of uprisings and mutinies in the units executing socioeducational measures once again ended up undermining the continuity of the policy. The new president eventually left office after persistent accusations by 
the Attorney General's Office and the Child and Youth Court.

Between 2000 and 2002, FEBEM was headed by a sociologist. It was during her term in 2002 that FEBEM was axed and Rio Grande do Sul's SocioEducational Service Foundation (Fundação de Atendimento Sócio-Educativo: FASE) created in its place. Maintaining the institution's policy since promulgation of the ECA, the 2000-2002 term also associated changes in the FEBEM/ FASE structure with the need to change values, concepts and individual awareness. This was perhaps the high point of the discourse on change. The document Evaluation and Systematization of the 2000-2002 Term explains the challenge that lay ahead: "It is clear that change is a process, and a slow and gradual one. To change hearts and minds is no easy task" (FASE 2002: 5).

To change - this was the keyword. The ongoing change was not perceived as just an alteration of legal principles: it was necessary to change hearts and minds. On the front cover of the same assessment report, the head of the institution highlighted the need for 'another consciousness' in order to 'change consciousness': "No consciousness can be changed by the same consciousness. Another is needed to promote change" (Albert Einstein, cited in FASE 2002: 4). Such insistence on change translated into hiring new employees and assembling a workforce that was 'new' to FEBEM/FASE. The 2000-2002 assessment report included an overview of FASE's staff: in 2002, 41\% of the new institution's 1,660 employees had been hired recently between 1999 and 2002. It is interesting to note, however, that even though close to half of the staff had been recently hired (not counting the 240 that entered in 1998), the discourse about an 'institutional culture' and an 'old paradigm' of service would still circulate in the daily routine of the institution, sustaining proposals regarded as being in tune with 'legal modernity.'

\section{Restorative Justice and the Management of Subjectivity}

Another facet of the configuration of meanings associated with legal change may be evinced from the process of implementing 'restorative justice' in Brazil, a subject that I have been following since 2006. In these processes, just as in other legal modalities of what Beraldo de Oliveira (2010) has called 'dialogue-based justice,' such as the Balcony of Rights and Community Justice, we can observe a criticism of legal formalism and a revision of operational 
procedures associated with legal positivism. ${ }^{8}$ In my research on restorative justice, it became clear that the legal knowledge embedded in the new language of 'child and adolescent rights' is permeated with an idiom of feelings that brings emotion to the forefront of changes in the management of children and adolescents. In fact even before the official implementation of pilot projects for 'restorative justice' in the Brazilian cities of Porto Alegre (Rio Grande do Sul), São Caetano (São Paulo) and Núcleo Bandeirante (Federal District) in 2005, the emphasis on a certain kind of 'modern' affect was part of the repertoire of professional training in the field of children and adolescents. 9

This sensibility was manifested in the professional capacity-building initiatives involving socio-educational agents. These training courses placed an emphasis on the inner self and promoted the value of the individual in the management of social conflicts. They also expressed an ideal of pacifying society through better management of individual subjectivities. Professionals at the Peace University (Universidade da Paz: UNIPAZ) played a frequent role in this professional training. They elaborated the notion of a 'crisis of meaning' that could only be overcome by promoting a 'culture of peace,' which could be achieved through greater self-awareness and the subjective transformation of by individuals. For these intervening agents, a key element in this learning process towards peace was precisely a need for self-transformation, as a requirement for changing the children, adolescents and families they attended to. This fascination with a search for peace through the management of subjectivities found a fertile ground in 'restorative justice,' thus becoming an appealing factor in the acceptance of this proposal in the resolution of legal conflicts.

In other words, in Brazil 'restorative justice' is presented as an 'alternative justice,' as it aims to break away from the traditional legal system's penal function, considered authoritarian and excessively punitive. It stresses negotiation and arbitration in the resolution of disputes and assumes the promotion of peace as its core value. In this process, it has been heavily influenced by UN recommendations for countries to introduce alternative systems to

8 On the field of arbitration and new legal experiences that seek to break with legal formalism, also see Melo and Baptista (2011) and Sinhoretto (2007).

9 On this topic, see Schuch (2006, 2009). With respect to restorative justice programs in Brazil, we can also note other ongoing experiences, for instance those being implemented in the states of Santa Catarina and Recife. These programs, however, were not part of the pilot projects. 
traditional state justice, including restorative justice and arbitration policies. ${ }^{10}$ The origins of this form of conflict resolution have been the subject of frequent debate among anthropologists and legal agents. There is however some consensus that proposals for its implementation in legal systems first emerged in countries such as the United States, Canada and New Zealand. Its growth during the 1970 and 80 s has been associated with what became known as Alternative Dispute Resolution, or conciliatory styles of dispute resolution (Nader 1994).

As in other contexts where alternative dispute resolution has been deployed, in Brazil restorative justice is being promoted as part of a fundamental process of reconfiguring representations of the nation state: from apartheid to 'truth telling' in South Africa (Buur 2001; Fassin 2007; Norval 2001; Ross 1997), the 'status quo war' in Nigeria (Last 2000), or from "adversarial society to social harmony" in the United Sates (Nader 1994). My analysis has indicated a movement from 'violence to peace' in Brazil. Along with its presence in other contexts, it is accompanied by a discourse on national modernization and development (Simião 2007; Rodrigues Pinto 2007; Soares 2007).

In Brazil, the program has been officially implemented since 2005 through technical cooperation between Brazil's Ministry of Justice, the Special Human Rights Secretariat, and the United Nations Development Program (UNDP). It is associated with other projects intent on 'modernizing' justice, which are being promoted by the Judiciary Reform Secretariat created in 2003 under the Ministry of Justice. ${ }^{11}$ An analysis of the available documentation shows that the entity's investments are driven by two major concerns: technical improvement, and the 'humanization' of the Brazilian justice system - that is, the implementation of restorative justice, which combines calls for modernizing justice and promoting peace with encouraging new truth-producing procedures. One of my hypotheses is that these elements have involved changes that are not limited to the Brazilian legal tradition.

10 See UN Social and Economic Council Resolution 26 of July 28, 1999.

11 With the purpose of helping the Brazilian government to modernize the state apparatus and prevent crime, UNDP invested 150 million US dollars in this technical cooperation project. The project's actions are based on a diagnosis of the best initiatives in Brazilian justice carried out in 200o. The latter was also made possible by international investment - this time, funds from the Inter-American Development Bank. These facts are significant given the claim that Brazilian legal changes respond in fact to national needs. These nonetheless appear in a context of international pressure for legal reforms driven by a neoliberal context that - as Santos (2000) puts it - has elected the Judiciary as guardian of the non-interventionist state. 
They introduce values and practices closely associated with the negotiation of truth and the adversarial paradigm of conflict resolution. But they also introduce values and principles to the formation of new ethical subjects in Brazil, as well as to certain government practices that operate according to notions of individual autonomy and responsibility in the management of one's own life.

\section{“Projects are Utopias": restorative justice and its multiple motivations}

In the educational materials presented by Dr. Rafael, the judge who coordinated restorative projects in Porto Alegre up to 2010, the remark that "projects are utopias" expressed the set of ideas underpinning restorative practices. The judge placed emphasis on the possibility of a paradigm shift: that is, a change in the 'lenses' with which conflict resolution is seen by society. To this end he has been actively involved in constructing a legal system that operates closer to the population. This strategy is accompanied by notions of personal engagement in changing legal structures - hence his reputation in the field of children and adolescents, where he has been working as a magistrate since 1994. As one of the pioneers of restorative practices in Brazil, Dr. Rafael has achieved national and even international standing. His reference to the fact that "projects are utopias" - understood in the sense of chimera, fantasy, something unrealizable - is significant insofar as it reveals a perceived gap between what exists and what is imagined and idealized. This space legitimizes the intervention of legal agents, and attributes them with a specific sense of working not only with established facts, but with the creation of a future, something that exists only virtually. What is being proposed is a project for society characterized by peace and harmony, one capable of being brought into existence by changing the ways in which conflicts between people and their fundamental values are conceived.

This 'utopia'-like project of society is vested with religious meanings for some of the agents participating in the implementation of restorative justice. Cinara, the teacher presented at the start of this article and who has been working in implementation the program since 2007, calls attention to the 'messianic' character of restorative justice in her claim that her religious upbringing has brought her closer to restorative justice. In Cinara's words: 
I think there is something else that puts me in tune with this project, which is my Christian religious background. I have no problem with messianism. For some, it seems like a magical solution, but it is a magical solution brought about by people. It is more or less what Jesus set out to do. If you pay attention, in Restorative Justice you will find debates on Judaic and Christian forgiveness. In Howard Zehr's book "Switching the Lenses" there is some of this discussion about Judaic forgiveness, which always supposes restoration. But I am also at ease with my messiah, who, if he has to forgive, always forgives. I have no problem with forgiving. I am not that worried if the person has ever done anything to me...

Besides this stress on the messianic aspect of social transformation, Cinara highlights the importance of her values of care, charity, and forgiveness in this intersection between her religious denomination and her affiliation with the team implementing restorative justice:

I think Restorative Justice relates to these principles of care and charity. With respect to spirituality, I think I fully identify with Jesus and with what he says. I shall be sympathetic towards forgiveness and towards spirituality, which is something that I think is present both in Restorative Justice and in my religion, and has always been part of my formation.

This association between restorative practices and religious principles became evident in a brochure explaining restorative justice and guidelines for restorative circles released in 2007, aimed at students on introductory courses in restorative practices. In a sort of ecumenical religious service held in the facilities of Porto Alegre's Justice Court, Dr. Rafael distributed a 'Saint Angel' prayer leaflet and asked Friar Lucas to bless the brochure, which he called "the DNA of the new justice system." While Friar Lucas - who was the manager of a protection center for children and adolescents in one of the city's outlying districts - blessed the brochure, all those present held hands in communion.

This intersection between religion and law is not exclusive to those who implement the project. Rodolfo - a white lawyer in his forties, an expert in family law and currently a volunteer facilitator in restorative practices - remarked that he had always tried to arbitrate in his professional activities, even before he became involved in restorative justice. He had switched between various college majors (such as business and computer science) before 
graduating in law. He remarked that on one occasion, when he used arbitration during a professional activity, the ex-husband of the client he was representing complimented him. Jokingly, he asked whether Rodolfo was really a lawyer and not a priest. During our conversation, Rodolfo jested about this situation, but remarked that peace and making people more sensitive towards greater self-knowledge and emotional control was vital for any process of social change.

An expert in 'biocentric' education and a 'biodance' instructor, Rodolfo brought to restorative justice an emphasis on emotions and on the importance of expressing them through the body. In the professional training sessions in which I participated, Rodolfo always remarked on the difference between transformative mediation, which taps into individual sensibilities, and negotiational mediation, which aims to solve problems without any subjective transformation. During capacity-building activities, Rodolfo would propose practices of bodily sensitization. On one such occasion, he a biodance colleague proposed a 'circular dance' to integrate all the trainees on one of the restorative justice courses through a rite celebrating their 'graduation' from the Rio Grande do Sul Judges Association (Associação dos Juizes do Rio Grande do Sul: AJURIS). The circular dance aimed to celebrate life, integration and emotional expression through the body and repeated bodily movements. At the same time, it put the group in touch with immemorial indigenous practices, stressed by the activity's coordinator as a great inspiration for restorative justice. On this occasion, it became evident how the event's physical space constrained the activity in important ways, since the formality of the AJURIS auditorium and its rectangular shape made the dance's circular configuration difficult to maintain. It was significant, though, that the space in question was occupied by a series of intervention agents, activists and other youth and adolescent service professionals - including Judge Rafael - who danced and repeated bodily integration movements, even though the unusual situation provoked embarrassed laughter from some.

Several participants therefore indicated that their own motivations stemming from religious experience and other technologies of constructing the self - played a prominent role in their participation in this legal innovation project. But there was also an insistence on the importance of methods to the success of restorative justice. On this point, Suely, the technical implementation manager for restorative justice in Rio Grande do Sul, is emphatic: 
the greatest innovation of restorative justice resides in its method - in Porto Alegre, so-called Non-Violent Communication. ${ }^{12}$ Suely is a white woman in her forties, and had been temporarily hired to work in the management of the restorative justice project. She has been in this position since 2007. Before then she had worked for approximately ten years at SOS Villages (Aldeias SOS), an institution sheltering socially vulnerable children and adolescents. She was also president of the city's Child and Adolescent Council. Part of a wide network of professionals working in the field of children and adolescents, she was invited to work with the community outreach program for restorative justice in Porto Alegre, since the project's first two years were limited to the legal field. Quite experienced in social intervention projects, she emphasized the method as the most appealing aspect of restorative justice:

There are things in Restorative Justice that I take from my own experience, very basic things. I think its biggest contribution is its method. I go to some schools and people say: but I already do that! Then I say, oh really? I think the great advantage of Restorative Justice is that it has systematized a method, and I think in this it has drawn a lot from Non-Violent Communication. It all depends on how you offer the possibility of negotiation between the parties. Well, my father also used to do this: he would put my sister and me in a room and tell us that we would only be allowed out after we worked out our differences. But as my father got tired and left, my sister and I would come to an agreement: let's pretend we are getting along again, and we'll resume our fight later. So it was a pact between us, and for him that had supposedly led to our reconciliation. Thus the idea of inviting people to solve their conflicts is nothing new, even indigenous ways worked like that, my father worked like that. But how did my father present this method? You two are sisters, you have to be on good terms. It didn't necessarily solve the conflict, but he conveyed many values to us at

12 The pilot projects for implementing restorative justice in Brazil differ in terms of the methodologies used in the restorative circles or meetings. The pilot projects in Rio Grande do Sul and São Paulo have privileged 'Non-Violent Communication,' a method created by a U.S. psychologist drawing on Carl Rogers - a well-known American psycho-pedagogue who developed a humanistic approach and a theory known as the Person-Centered Approach. The pilot project in the Federal District deploys, for its part, the 'victimoffender arbitration' methodology, drawing on the Brazilian law professor and arbitration expert André Gomma. Academic trends in law have tended to influence the Federal District's restorative justice projects more heavily than the emphasis on psychology. But even the victim-offender arbitration method derives from legal theoretical currents in the United States. Further details on the implementation of restorative justice in the Federal District can be found in Spagna (2008). 
that moment... For him, we had to make up, and he deployed a whole repertoire of ideas to this end: because we shared the same blood, because he was our father, and so forth (...) Anyway, people want peace, people search for peace, how do you go about doing it? Restorative Justice has systematized a methodology for doing just that.

In her view, the methodological roadmap established by restorative justice offers an opportunity for bringing about conflict resolution in a nonviolent manner. As such, it shows certain connections with other experiences of the same kind (as in the case of her family experience), but exceeds them in its ability to systematize relationships. As we shall see, the Non-Violent Communication method enables subjectivities to be engaged as a means to resolve social conflicts, and as a consequence, to help create a harmonious society. This methodology of restorative meetings emphasizes self-responsibility, a display of the participants' interiority, and implies the preeminence of a structuring subjectivism.

\section{Constituting the 'Universal' and Non-Violent Communication as a Method for Restorative Justice}

The justification for restorative justice in Brazil differs from the one associated with alternative dispute resolution in the United States, where the harmonization of conflicts is advocated as a response to an excessively litigious and legalistic society (Nader 1994). In Brazil justification is based on the degree of violence observable in Brazilian society. Social violence is taken as a symptom and expression of non-harmonious and especially disintegrative relations.

The danger of anomy, of the inexistence of values supporting common social existence, is key to the search for alternative practices to the litigious model. In this view, social restoration is predicated on individual transformation. The emphasis is placed on the individual as a value. This resonates with the values that underpin American society. Interestingly enough, the psychologist who constructed the methodological model that has been used in capacity-building for restorative practices in Rio Grande do Sul - namely, the NonViolent Communication (NVC) method - was himself American.

According to publications that disseminate this methodology, Marshall B. Rosenberg, a doctor in clinical psychology and founder of the International Non-Violent Communication Center, developed NVC, which emerged from 
the observation that increasing levels of violence are the outcome of a logic of action and relationships that is divorced from our true values, and that starts off cycles of painful emotions. The NVC method is presented as enabling structural changes in the way human relations are faced and organized, making it suitable for organizational and group management. However as a self-help method, NVC may be also applied to the management of extra-institutional, interpersonal relations. According to its educational materials, NVC was first deployed in schools and public institutions during the 1960s as part of U.S government projects. In a context of growing demands for arbitration in American society, in 1984 Rosenberg hired professionals to create the NonViolent Communication Center in California. This organization offers training courses in arbitration in various countries, including England - where many of the Brazilian theoreticians of restorative justice completed their graduate studies.

Also from England came the consultant in charge of implementing NVC in Brazil, to whom I shall refer here as Michel. A former theater actor, he is part of an extensive network of professionals who, after training in NVC, became international consultants in charge of disseminating a technique based on the belief that the expression of emotion is necessary to be able to resolve problems. This involves suspending judgment and nurturing a potential for compassion, care and cooperation - all understood in opposition to violencegenerating intolerance. One of the first tools for social change is to transform each individual's ability to recognize and express his or her own emotions and needs. The assumption is that there are universal human needs that enable the construction of a shared code for guiding social interactions within restorative circles.

According to this code, emphasis is placed on the values of harmony and individual responsibility for conflict resolution. These values are explicit at each stage of the 'restorative circles,' and are learned by all participants in restorative justice courses and workshops. These circles - which have to be experienced rather than acted out or represented - are based on real life situations. Each stage is experienced several times by the trainees, and is then discussed with the NVC consultant, who comments on each case. Weeping and emotional testimonies are part of this process, which seeks to change those who practice it. The idea is that it is necessary for the subject to transform him or herself first, before he or she can become a coordinator of a 
restorative circle. This methodology involves meetings between victim, offender and other people involved in the offense, 'facilitated' by a circle coordinator and a co-coordinator.

Each circle has three stages: the moment of mutual understanding (how are you feeling today about the incident?); the moment of responsibilization (what were you looking to achieve through that action? what was your need at that moment?); and the deal (what do you have to offer or ask for?). The basic questions at each stage should be reciprocally asked to each participant until each one recognizes that he or she understood exactly what the other meant. It should also be noted that this methodology is not merely passed on to the circle participants: the implementing agents constantly train the participants in the correct techniques. Suely, the social worker who works as a manager in the implementation of restorative justice in Rio Grande do Sul, underscores the daily training implicated in the methodology and its outcomes:

As we delve deeper into this process, we feel as if we are becoming better people. I began to experience this internally. I submitted to the method, and would tell my children: mom is doing this method! I would mediate small conflicts at home according to the methodology, and it's very interesting how people who used to think differently would start to realize the method's credibility. I had an emotional identification with this process. Not all of us are emotionally connected with our professional activities, but I was (...) The project showed me this, it's wonderful to be able to deal with one's own conflicts. This is the project's greatest potential. And no one is impervious to the project. We all have a lot of raw material to work upon.

Just like Cinara, who stressed a subjective shift towards becoming less 'explosive,' Suely highlighted an improvement in her ability to 'listen' and to transform herself:

I am a chatterbox, I have an ability to speak, and I think I have become more aware of the need to listen. I think that after the project I began to listen more. I sought to improve this ability (...) I am not predisposed to fighting anyway, but certainly the project has made me a more attentive listener, and has also encouraged me to become a better person. I think all of us can become better people, it's a gradual change, but everyone can. I feel like I am more 'zen' now, more focused on things. 
One of the most interesting remarks made by Suely referred precisely to the self-responsibilization that the restorative justice method offers or enables through its principles for action. She emphasized the value of individual management of what will be gained from one's relationships. In other words, Suely pointed out that the restorative justice method leads to self-responsibility, a new relation between individuals and their selves, their actions and those of other persons. In this sense, restorative justice may be regarded as a technology for managing subjectivities, in the terms put forth by Michel Foucault (1986). This suggests research on forms of subjectification, understood as practices which lead individuals to pay attention to themselves, to decipher and recognize themselves, and to establish with themselves a relation that allows them to uncover their true selves. This way of posing the problem of forms of subjectification is related to a set of practices Foucault (1986) referred to as the 'arts of existence': reflexive and voluntary practices through which people not only establish rules for conduct, but also seek to change their own unique being and make their life into a piece of work that carries certain esthetical values and responds to certain criteria of style (Foucault 1986: 15). In my understanding, Suely underscored precisely these aspects of the transformation of the self in the process of learning and putting to use the methodology proposed by restorative justice. In this process, she also established an ideal for herself: to become a better person, in a constant practice of reflexive self-transformation. In her words:

I also learned that the magnitude of things is set by yourself. Something is very big or very small according to the size you yourself ascribe to it (...) My pain is how I feel it. If the other wished to attack me, that's his or her responsibility. Self-responsibilization is another great aspect of the project, because we tend to hold the other responsible. (...) For example, if we get slapped on the face, of millions of possibilities, that person chose to slap me on the face. Of millions of possibilities, I may choose to slap him or her on the face, or not. But this is a difficult exercise, because it demands self-responsibilization. When I take responsibility, I do it for the degree of aggressiveness that I show. Indeed self-responsibilization is nothing more than this acknowledgement: that I am a bomb, I am not that much of a bomb, if I get hurt I shall react ... It's about discipline. Because I think we live in a very aggressive culture. 
The example chosen by Suely to illustrate the value of subjective choice about the reaction that a certain act is bound to elicit, as well as the choice made by the slapped person concerning his or her own reaction, is meaningful for two reasons. First, it opens up the possibility for including management of the self in the configuration of social conflicts. In this sense, the self assigns a magnitude to acts that are external to it; there is, therefore, a separation between the external world and the world of the self, which reconfigures the former in terms of the latter. Second, the very form by which the need to work on the construction of the self (to choose the magnitude of problems) as well as on self-awareness and self-discipline (to recognize one's personal traits and pay heed to their management) suggests important elements for analysis. In other words, the way in which this relationship was made explicit suggests to the listener an association with the Christian guidance of offering the other cheek. According to Christian principles, offering the other cheek promotes not just the notion of forgiveness, but a new principle of justice: not the lex talionis- an eye for an eye, a tooth for a tooth - but a merciful justice, a justice of love and charity. ${ }^{13}$

Through Suely's words, it is possible to combine a morality and a practice of the self. I suggest that here we may envisage a possible interpretation for the appeal of restorative justice, as well as an analytic framework for understanding it - relating the process of constructing the self triggered by restorative practices to a moral conduct in which religious, family and professional elements are interwoven. Michel Foucault (1986) uses the term "morality of behaviors" for the intersection between the set of values and rules for action proposed to individuals and groups by various prescriptive apparatuses (family, school, church and so forth) and the actual behavior of individuals in relation to the rules and values that are proposed to them. Foucault argues that there is no moral action that does not refer to the unit of a moral conduct, neither is there a moral conduct that does not imply the constitution of oneself as a moral subject. At the same time, there is no constitution of a

13 This association is manifested, for instance, in Jesus's words to Matthew in the New Testament: "You have heard that it was said, 'Eye for eye, and tooth for tooth.' But I tell you, do not resist an evil person. If anyone slaps you on the right cheek, turn to them the other cheek also. And if anyone wants to sue you and take your shirt, hand over your coat as well. If anyone forces you to go one mile, go with them two miles. Give to the one who asks you, and do not turn away from the one who wants to borrow from you" (Matthew 5, 38-42). 
moral subject without modes of subjectivation - that is, without "practices of the self" that sustain it.

My inquiry into the views held by those who implement restorative practices in Rio Grande do Sul concerning their own work shows an association between codes of behavior (religious, family and professional orientation) and new forms of subjectivation (management of subjectivities with expression of one's inner self, self-responsibilization practices, etc.) brought about by their experiences with and constructions of meaning around restorative practices. These heterogeneous circuits seem to suggest the operation of two kinds of logic in child and adolescent policies. One is an emphasis on the subjectively engaged advocacy of legal agents, supported by the mission to 'help,' 'protect,' and 'save' children and adolescents. This involves a quest for a pacified society, which now has the chance to flourish backed by the legal guarantees enshrined in the new instruments for protecting rights set out in the 1990 Child and Adolescent Statute. The other logic involves the evocation of a way of constructing subjectivities that allows the inner self to surface and promotes self-responsibility, self-discipline, and a constant reworking of the self through reflexive practices that are regarded as vital for creating new ways of managing conflict. This new intervention technology has found fertile ground precisely because of its capacity to match ideals of social and community harmonization. There is, therefore, a mutual reinforcement between moral codes of behavior (religious, family and professional orientations) and new forms of subjectivation.

\section{Final Remarks}

The implementation of new practices in Brazil's child and adolescent justice system has brought together a set of diverse actors - legal agents, transnational development and human rights organizations, teachers, community leaders, international experts and consultants, mothers' clubs, among others. In a way, this reflects the formation of a new field of intervention aimed at national development and modernization. These agents and agencies form heterogeneous networks in which various kinds of power circulate to create dominant meanings about contemporary processes, as well as the exercise of practices. The field of implementation and dissemination of new proposals for social intervention is far from homogenous, therefore, at least with 
respect to juvenile offender services in Rio Grande do Sul. Nonetheless, it is possible to discern the hegemony of a set of discourses that brings together notions of self-suggestion and individual transformation as part of the modernization of justice and the promotion of a culture of peace.

As part of this project of social change, emically associated with a mission, legal agents have championed projects and programs, as well as a rhetoric of breaking with practices and values associated with the so-called 'traditional culture' for attending to children and adolescents in Brazil. More than a sociological reality, the rhetoric of a rupture must itself be subjected to analysis. As I sought to demonstrate, there is a particular and dynamic intersection between the meanings that legal-state agents ascribe to the implementation of legal change, and their religious and welfarist orientations. These orientations provide fertile ground for the incorporation of a new legal technology - restorative justice - that operates by managing subjectivities and so-called non-violent modes of dispute resolution.

Even though legal agents have constructed a discourse based on a rhetoric of change, and my analysis has suggested a certain intersection between what could be classified as a code of 'rights' and a code of 'aid,' I do not wish to convey the idea of a 'gap' or 'deficit' in the dissemination of child and adolescent rights. On this point, I borrow the argument advanced by James Ferguson (2006) in his study of an agricultural development project for fighting poverty in Lesotho: it is important to privilege not what projects fail to achieve, but precisely what they do achieve, their 'side effects.' In this sense, projects for legal change based on a new rhetoric of child and adolescent rights may be regarded as promoting change not only in a legal sense: the very introduction of such rhetoric provides an opening to other kinds of intervention.

This paper has argued that the practices breathing life into restorative justice may be more productively understood in terms of an 'explosion' of the formal institutional fields in which it takes place. This occurs through the threefold character of subjectivity: as an analytical category; as an instrument through which new forms of government come into being; and as a 'ground for agency.' In my research, the intersection between the religious and family moral background of the implementing agents, on one hand, and other technologies for constructing the self and managing individual subjectivities that foreground autonomy and self-responsibility, on the other, generates a sui generis constellation of universalist values and individualistic principles. 
This becomes part of a powerful control apparatus: to enter a political community that is, in emic terms, synonymous with 'humanity' itself, comes to require continuous individual commitment and responsibilities from those subjected to it.

\section{References}

ABU-LUGHOD, Lila. 2003. "Melodrama egípcio: uma tecnologia do sujeito moderno?" Cadernos Pagu, n. 21: 75-102.

ALMEIDA, Dom Luciano Mendes de. 2001. "Comentário de Dom Luciano Mendes de Almeida”. In: M. Cury; A. F. do Amaral e Silva; E. García Mendez (eds.). Estatuto da Criança e do Adolescente comentado: comentários jurídicos e sociais. São Paulo: Malheiros Ed. pp.13.

AMARAL E SILVA, Antonio Fernando. 199o. "A Justiça da Infância e da Juventude”. In: Brasil Criança Urgente: a lei 8060/9o. SP: Instituto Brasileiro de Pedagogia Social/Columbus Cultural. PP 77-78.

ASHER, Kiran. 2004. "Engendrando Desenvolvimento nas Terras Baixas do Pacífico Colombiano". In: Revista Estudos Feministas. N. 12 (1): 15-45. BERALDO DE OLIVEIRA, Marcella. 2010. Justiças do Diálogo. Uma Análise das Mediações Extrajudiciais. Doctoral theses presented to the Postgraduate Program in Social Sciences, UNICAMP, Campinas.

BIEHL, João. 2004. "Ciência, tecnologia e saúde mental". In: A. Leibing (ed.), Tecnologias do Corpo. Uma antropologia das medicinas no Brasil. Rio de Janeiro: NAU Editora. pp. 19-35.

BIEHL, João. 2005. "A vida cotidiana das palavras: a história de Catarina". Cadernos da APPOA. Porto Alegre, no 140:14-29.

BIEHL, João and ESKEROD, Torben. 2005. Vita. Life in a zone of social abandonment. California: California University Press.

BIEHL, João and ESKEROD, Torben. 2007. Will to live. AIDS therapies and the politics of survival. Princeton, Oxford: Princeton University Press.

BIEHL, João, GOOD, Byron and KLEINMAN, Arthur (ed.). 2007. Subjectivity. Ethnographic Investigations. Berkeley, Los Angeles and London: University of California Press.

BONETTI, Alinne. 2001. "Novas Configurações: direitos humanos das mulheres, feminismo e participação política entre mulheres de grupos populares porto-alegrenses". In: R. Kant de Lima and R. Novaes (ed.). 
Antropologia e Direitos Humanos. Prêmio ABA/Fundação FORD. Niterói:

Editora da Universidade Federal Fluminense. pp. 137-201.

BOURDIEU, Pierre. 1989. O Poder Simbólico. Rio de Janeiro: Bertrand Brasil.

BUUR, Lars. 2001. "The South African Truth and Reconciliation Commission: a technique of Nation-State Formation”. In: B. Hansen and F. Stepputat. States of Imagination. Ethnographic Explorations of the Postcolonial State.

Durham: London, Duke University Press. pp. 149-181.

BRASIL. 1990. Estatuto da Criança e do Adolescente.

CARDOSO DE OLIVEIRA, Luis Roberto. 2002. Direito Legal e Insulto Moral.

Dilemas da Cidadania no Brasil, Quebec e Estados Unidos. RJ: Relume Dumará. CARDOSO DE OLIVEIRA, Luis Roberto. 2010. “Concepções de igualdade e (des)igualdades no Brasil”. In: R. Kant de Lima; L. Eilbaum e L. Pires. (ed.) Conflitos, Direitos e Moralidades em Perspectiva Comparada - Volume 1. Rio de Janeiro: Garamond. pp. 19-33.

DEBERT, Guita Grin and BERALDO DE OLIVEIRA, Marcella. 2007. “Os modelos conciliatórios de solução de conflitos e a "violência doméstica". In: Cadernos Pagu (29): 305-337.

DEZALAY, Yves and GARTH, Bryant G. 1996. Dealing in virtue. International arbitration and the construction of a transnational legal order. Chicago and London: University of Chicago Press.

FASE. 2002. Gestão 2000-2002. Avaliação e Sistematização. Porto Alegre: Fundação de Atendimento Sócio-Educativo do Rio Grande do Sul. pp. 1-132.

FASSIN, Didier. 2007. When Bodies Remember. Experiences and politics of AIDS in South Africa. Berkeley e Los Angeles: University of California Press. FERGUSON, James. 2006. “The Anti Politics Machine”. In: A. Sharma and A. Gupta (eds.). The Anthropology of the State. A Reader. Oxford: Blackwell Publishing. pp. 270-286.

FERREIRA, Jaqueline and SCHUCH, Patrice. 2010. Direitos e Ajuda

Humanitária: perspectivas sobre familia, gênero e saúde. RJ: Editora da FIOCRUZ. pp. 151-181.

FONSECA, Claudia. 1995. Caminhos da Adoção. São Paulo: Cortez. FONSECA, Claudia. 200o. Familia, fofoca e honra: a etnografia de violência e relações de gênero em grupos populares. Porto Alegre: Editora da UFRGS. FONSECA, Claudia. 2004. "Os direitos da criança: dialogando com o ECA”. In: C. Fonseca; V. Terto and C. Alves (eds.). Antropologia, diversidade e direitos humanos: diálogos interdisciplinares. Porto Alegre: Editora da UFRGS. 
FONSECA, Claudia. 2010. “Ordem e Progresso” à Brasileira: lei, ciência e gente na "co-produção" de novas moralidades familiares". In: J. Ferreira and P. Schuch (eds.). Direitos e Ajuda Humanitária: perspectivas sobre familia, gênero e saúde. RJ: Editora da FIOCRUZ. pp. 151-181.

FONSECA, Claudia and CARDARELLO, Andrea. 1999. "Direitos dos mais ou menos humanos”. Horizontes Antropológicos. Year 5, n. 10, May 1999: 83-121. FONSECA, Claudia and SCHUCH, P. (eds.). 2009. Políticas de Proteção à Infância: um olhar antropológico. Porto Alegre: Editora da UFRGS. FOUCAULT, Michel. 1979. “A Governamentalidade”. In: Microfísica do Poder. RJ, Edições Graal. pp. 277-293.

FOUCAULT, Michel. 1986. "Introdução. A problematização moral dos prazeres”. História da Sexualidade 2: O uso dos prazeres. Rio de Janeiro: Graal. pp. $07-32$.

FOUCAULT, Michel. 2006. Seguridad, Território, Población: curso en el Collège de France: 1977-1978. Buenos Aires: Fundo de Cultura Econômica.

GARDNER, James A. 1980. Legal imperialism. American lawyers and foreign aid in Latin America. Madison: University of Wisconsin Press.

GREGORI, Maria Filomena. 200o. Viração: Experiências de Meninos nas Ruas. São Paulo: Companhia das Letras.

GREGORI, Maria Filomena; SILVA, Cátia S. 2000. Meninos de Rua e Instituições.

Tramas, Disputas e Desmanche. São Paulo: Contexto.

GUPTA, Akhil. 2001. "Governing Population: the integrated child development services program in India”. In: B. Hansen and F. Stepputat (eds.). States of Imagination. Ethnographic Explorations of the Postcolonial State. Durham and London: Duke University Press. pp.65-95.

KANT DE LIMA, Roberto. 1989. “Cultura Jurídica e Práticas Policiais. A Tradição Inquisitorial”. Revista Brasileira Ciências Sociais. n. 10, vol. 4: 65-84. KANT DE LIMA, Roberto. 1995. A Polícia da Cidade do RJ: seus Dilemas e Paradoxos. RJ: Forense.

KANT DE LIMA, Roberto. 1999. "Polícia, Justiça e Sociedade no Brasil: uma Abordagem Comparativa dos Modelos de Administração de Conflitos no Espaço Público”. In: Revista de Sociologia e Política. Curitiba, n. 13: 23-38. KANT DE LIMA, Roberto. 2003. "Direitos Civis, Estado de Direito e 'Cultura Policial': A Formação Policial em Questão”. Revista Brasileira de Ciências Criminais. Year 11, n. 41: 241-256.

LAST, Murray. 2000. "Reconciliation and Memory of Postwar Nigeria”. In: V. 
Das; A. Kleinman; M. Ramphele e P. Reynolds. Violence and Subjectivity. Berkeley/Los Angeles/London: University of California Press. pp. 315-332. MACEDO, João Paulo. 2009. A Invenção da "Juventude Violenta”. Análise da elaboração de uma política pública. RJ: LACED/E-Papers.

MELLO, Kátia Sento Sé. 2011. Cidade e Conflito. Guardas Municipais e Camelôs.

Niterói: Editora da UFF.

MELLO, Kátia Sento Sé and BAPTISTA, Bárbara Gomes Lupetti. 2011.

"Mediação e conciliação no Judiciário: dilemas e significados”. Dilemas:

Revista de Estudos de Conflito e Controle Social. Vol. 4, n. 1: 97-122.

MINISTÉRIO DA JUSTIÇA. 2005. Acesso à Justiça por Sistemas Alternativos de Resolução de Conflitos. Mapeamento Nacional de Programas Públicos e NãoGovernamentais. Brasil: Ministério da Justiça. pp. 1-98.

MUNIZ, Jaqueline. 1996. “Os direitos dos outros e outros direitos: um estudo sobre a negociação de conflitos nas DEAMS/RJ”. In: L. E. Soares et al. Violência e Política no Rio de Janeiro. Rio de Janeiro: ISER/Relume Dumará. pp. $125-163$.

NADER, Laura. 1994. "Harmonia Coerciva: A Economia Política dos Modelos Jurídicos”. Revista Brasileira de Ciências Sociais. N. 26: 18-29.

NEVES, Delma Pessanha. 2010. “Políticas de 'Vitimização' e Direitos Sociais Seletivos". In: J. Ferreira and P. Schuch (eds.). Direitos e Ajuda Humanitária: perspectivas sobre familia, gênero e saúde. Rio de Janeiro: Editora da FIOCRUZ. pp. 77-104.

NORVAL, Aletta J. 2001. "Reconstructing National Identity and Renegotiating Memory: the work of TRC”. In: B. Hansen e F. Stepputat (ed.). States of Imagination. Ethnographic Explorations of the Postcolonial State. Durham and London: Duke University Press. pp.182-202.

OLIVEIRA, Carmen Silveira de. 2000. Decifra-me ou te devoro: um Balanço de 17 Meses na FEBEM. Document written in May 2000, accompanued by request to resign post. In: http://rolim.com.br.

ONG, Aihwa; COLLIER, Stephen (ed.). 2005. Global Assemblages Technology, Politics and Ethics as Anthropological Problems. Oxford: Blackwell Publishing.

ORTNER, Sherry. 1995. "Resistance and the Problem of Ethnographic Refusal". Comparative Studies in Society and History 37(1): 173-193.

ORTNER, Sherry. 1999. "Introduction”. In: ORTNER, Sherry (ed.). The Fate of Culture. Geertz and Beyond. Berkeley and Los Angeles: University of 
California Press. pp. 1-14.

ORTNER, Sherry. 2006. Anthropology and Social Theory. Culture, Power and the Acting Subject. Durham and London: Duke University Press.

PILOTTI, Francisco and RIZZINI, Irene (eds.). 1995. A arte de governar crianças:

A história das políticas sociais, da legislação e da assistência à infância no Brasil.

Rio de Janeiro: Instituto Interamericano Del Niño/Editora Universitária

Santa Úrsula.

RAMPHELE, Mamphela. 1997. "Political Widowhood in South Africa: the embodiment of ambiguity”. In: A. Kleinman and V. Das (eds.) Social Suffering. Berkeley and Los Angeles: University of California Press.

RIBEIRO, Fernanda Bittencourt. 1996. A Inserção do Conselho Tutelar na Construção do Problema Social da Infância e Adolescência. MA dissertation presented to the Postgraduate Program in Social Anthropology of the Federal University of Rio Grande do Sul, Porto Alegre.

RIBEIRO, Fernanda Bittencourt. 2009. "Conselho Tutelar e Negociação de Conflitos”. In: C. Fonseca and P. Schuch (eds.). Políticas de Proteção à Infância: um olhar antropológico. Porto Alegre: Editora da UFRGS. pp. 93112.

RIFIOTIS, Theophilos. 2007. "Direitos Humanos: sujeito de direitos e direitos dos sujeitos”. In: S. M. Silveira (ed.). Educação em Direitos Humanos: fundamentos teórico-metodológicos. João Pessoa: Editora Universitária. pp. 231-244.

RIVERA, Deodato. 1990. "A mutação civilizatória”. In: Brasil, criança urgente: a Lei 8069/9o. Coleção Pedagogia Social, v. 3. São Paulo: Instituto Brasileiro de Pedagogia Social/Columbus Cultural. pp. 34-37.

RODRIGUES PINTO, Simone M. 2007. “Justiça transicional: perspectivas para a reconciliação social”. In: K. C. da Silva and D.S. Simião. (eds.). TimorLeste por trás do palco: cooperação internacional e a dialética da formação do Estado. Belo Horizonte: UFMG. pp. 181-192.

ROSE, Nikolas. 1999. Powers of Freedom. Reframing Political Thought. Cambridge: Cambridge University Press.

ROSE, Nikolas. 2006. “Governing 'Advanced' Liberal Democracies”. In:

A. Sharma and A. Gupta (eds.). The Anthropology of the State. A Reader. Oxford: Blackwell Publishing. pp. 144 -162.

ROSS, Fiona. 1997. “Speech and Silence: women's testimony in the first five weeks of public hearings of the South African Truth and Reconciliation 
Commission". In: A. Kleinman and V. Das (eds.). Social Suffering. Berkeley and Los Angeles: University of California Press. pp. 250-28o.

SAHLINS, Marshall. 1997. "O 'pessimismo sentimental' e a experiência etnográfica: porque a cultura não é um 'objeto' em via de extinção” (Parte I). Mana, vol. 3, n. 1: 41-73.

SANTOS, Boaventura de Souza. 200o. "Por uma Concepção Multicultural de Direitos Humanos". In: B. Feldman Bianco (ed.). Identidades. Estudos de Cultura e Poder. São Paulo: Hucitec.

SCHUCH, Patrice. 2006. "Direitos e Sensibilidades: Uma Etnografia das Práticas de Justiça da Infância e Juventude”. In: M. P. Grossi; L. Z. Machado and M. L. Heilborn (eds). Antropologia e Direitos Humanos IV. Prêmio da ABA/Fundação Ford. Niterói:EDUFF. pp. 57-120.

SCHUCH, Patrice. 2008a. "A Judicialização do Amor: sentidos e paradoxos de uma justiça engajada”. Campos (UFPR), v. 9: 8-29.

SCHUCH, Patrice. 2008b. "Tecnologias da Não Violência e Modernização da Justiça no Brasil: o caso da Justiça Restaurativa”. Civitas (Porto Alegre), v. 8: 498-520.

SCHUCH, Patrice. 2009. Práticas de Justiça: antropologia dos modos de governo da infância e juventude no contexto pós-ECA. Porto Alegre: Editora da UFRGS.

$\mathrm{SCHUCH}$, Patrice. 2010. "Uma lei moderna $\mathrm{X}$ uma cultura tradicional: notas sobre reformulação do campo de atenção à infância e juventude no Brasil". Revista Brasileira de História e Ciências Sociais. V.2: 73-84.

SCHRITZMEYER, Ana Lúcia Pastore. 2007. "Etnografia dissonante dos tribunais do júri”. In: Tempo social. São Paulo: v. 19, n. 2:11-129.

SCURO NETO, Pedro. s/data. Justiça Restaurativa e a cultura da paz: do conceito ao contexto". Essay for introductory course in Restorative Justice of the JIJ. Porto Alegre (mimeo).

SIMIÃO, Daniel Schroeter. 2007. "Madam, it's not so easy': Modelos de gênero e justiça na reconstrução timorense”. In: K. C. da Silva and D. S. Simião (ed.). Timor-Leste por Trás do Palco: A Cooperação Internacional e a Dialética da Formação do Estado. Belo Horizonte: Editora UFMG. pp. 210-233.

SINHORETTO, Jacqueline. 2007. "Reforma da justiça: estudo de caso". In: Tempo social. Vol.19, n.2: 157-177.

SOARES, Dionísio da Costa Babo. 2007. "O Desenvolvimento do Setor de Justiça no Timor Leste”. In: K. C. da Silva and D. S. Simião (ed.). TimorLeste por Trás do Palco: A Cooperação Internacional e a Dialética da Formação do 
Estado. Belo Horizonte: Editora UFMG. pp. 193-210.

SPAGNA, Laiza Mara Neves. 2008. A Justiça Restaurativa no Distrito Federal.

Final dissertation for undergraduate course in Social Sciences, University of Brasilia, Brasilia (mimeo).

SPDCA/SEDH/PR. 2006. Levantamento Nacional de Atendimento Sócio-educativo para Adolescentes em Conflito com a Lei-2006. Brasília: Secretaria Especial de Direitos Humanos.

TSING, Anna Lowenhaupt. 2005. Friction. An Ethnography of Global Connection. Princeton: Princeton University Press.

VIANNA, Adriana de Resende B. 1999. O Mal que se Adivinha: Polícia e Menoridade no Rio de Janeiro: 1910/1920. Rio de Janeiro: Arquivo Nacional. VIANNA, Adriana. 200o. Limites da Menoridade: tutela, familia e autoridade em julgamento. Doctoral thesis completed at the Museu Nacional/UFRJ. Rio de Janeiro: PPGAS/Museu Nacional-UFRJ (mimeo).

VILLALTA, Carla. 2004. "Una Filantrópica Posición Social: Los Jueces en la Justicia de Menores”. In: S. Tiscornia (ed.) Estudios de Antropología Jurídica. Burocracias y Violencia. Buenos Aires: Antropofagia.

WILSON, Richard A. 2000. "Reconciliation and revenge in South Africa". In:

Current Anthropology. Volume 41 (1): 75-87.

WILSON, Richard A. 2007. "Human Rights, Culture and Context: an

Introduction". In: Human Rights, Culture and Context. Anthropological Perspectives. London and Sterling: Pluto Press. pp. 1-27.

\section{About the Author}

Patrice Schuch is Professor of Anthropology at the Federal University of Rio Grande do Sul, Brazil. Her research interests include child and adolescent rights, modes of government, human rights and citizenship in Brazil. She is the author of Práticas de Justiça: modos de governo da infância e juventude pós-ECA (2009). She has also co-edited the books Políticas de Proteção à infância: um olhar antropológico (2009), Direitos e Ajuda Humanitária: perspectivas sobre familia, gênero e saúde (2010), Ética e Regulamentação na Pesquisa Antropológica (2010) and Experiências, Dilemas e Desafios do Fazer Etnográfico Contemporâneo (2010).

Contact: patrice.schuch@uol.com.br

Received October 1, 2011, approved 14 December, 2011 